www.jmscr.igmpublication.org

Impact Factor 5.84

Index Copernicus Value: 71.58

ISSN (e)-2347-176x ISSN (p) 2455-0450

crossref DOI: _https://dx.doi.org/10.18535/jmscr/v5i10.172

Journal Of Medical Science And Clinical Research

IGM Publication

An Official Publication of IGM Publication

\title{
A Histopathological Study on Invasive Ductal Carcinoma Breast with Respect to ER/PR Status and Mast Cell Distribution
}

\author{
Authors \\ Dr Annu Sajeev ${ }^{1}$, Dr Arun Antony ${ }^{2}$, Dr Sarath Kumar ${ }^{3}$ \\ ${ }^{1}$ Department of Pathology, Government Medical, College Trivandrum \\ ${ }^{2}$ Department-Department of Surgery, Government Medical, College, Trivandrum \\ ${ }^{3}$ Associate Professor, Department of Pathology, Government Medical College, Trivandrum \\ Corresponding Author \\ Dr Annu Sajeev \\ 8B, AG-1, Vikaspuri, New Delhi 110018 \\ Email: drannusajeev@gmail.com, Mobile: 9496370593
}

\begin{abstract}
Introduction: When a carcinoma develops our immunity plays a major role in fighting against tumor cells. Mast cells which play a major role in our innate immunity are also found to get activated in a developing tumor. So far only few studies have been conducted on the role of mast cell in carcinoma breast which have shown the cytolytic activity of these on tumor cells and their relationship in response to hormone receptor status.
\end{abstract}

Aim: To study the histopathological characteristics of invasive ductal carcinoma breast. and mast cell count in them and their relationship with Estrogen \& Progesterone receptor status.

Materials and Methods: We did a descriptive histopathological study on the specimens of modified radical mastectomy received in the Department of Pathology, Government Medical College, Thiruvananthapuram from $1^{\text {st }}$ January 2012 to 2014. Histopathological characteristics of each case with respect to their ER/PR status was studied. Mast cell were stained using special stains and counted. Data was statistically analysed with SPSS software using Univariate analysis and chi square test to detect the significance of mast cell presence with receptor status in invasive ductal carcinoma breast.

Results: Out of total 150 cases the mast cells were present in 56 cases (37.3\%) and were absent in 94 cases (62.7\%). The relationship between presence of mast cells and estrogen and progesterone receptor positivity was found to be stastically insignificant as the p-value was more than 0.05. Thus there was no significant relationship between estrogen and progesterone receptor status with the presence of mast cells. Conclusions: The present study showed that there is no significant relationship between presence of mast cells in peritumoral tissue and the hormonal status of the patient. So as per this study mast cell presence cannot be suggested as a definitive cheap easily assessable prognostic factor in carcinoma breast. Newer modalities for detection of new prognostic indicators can help in implementation of adjuvant therapies in a patient with ductal carcinoma breast. 


\section{Introduction}

Among the various cancers carcinoma breast is the most common cancer among women in developed countries and is the second most common cancer among Indian females. Developmentally, the female breast is under the control of estrogen and progesterone. So these hormones play a strong role in the causation of breast cancer. It can be of 2 types- ductal and lobular of which Invasive Ductal Carcinoma (IDC) is the commonest form.

When a carcinoma develops our immunity plays a major role in fighting against tumor cells. Mast cells which play a major role in our innate immunity are also found to get activated in a developing tumor. So far only few studies have been conducted on the role of mast cell in carcinoma breast which have shown the cytolytic activity of these on tumor cells and their relationship in response to hormone receptor status.

Various studies have been conducted to find out the relationship between the hormone receptor status and cellular status in tumor microenvironment.

The invasive breast carcinomas is graded histologically as per the Nottingham modification of the Scarff-Bloom-Richardson grading system which grades breast carcinomas by adding up scores for tubule formation, nuclear pleomorphism, and mitotic count. The scores for each of these are added together to give an overall final score and corresponding grade for IDC.

The Clinical Grading is using TNM staging. Lower the stage betters the prognosis.ER and PR status is assessed as per Allred score. Positivity for these receptors favors good prognosis.

A study is being planned to find out histopathological characteristics of invasive ductal carcinoma breast in our setup and to find out the relationship of mast cell distribution in invasive carcinoma breast with respect to various grades and their ER/PR status.

\section{Materials and Methods}

Study Design: Descriptive study
Study Setting: Department of Pathology, Government Medical College,

Thiruvananthapuram.

Study Period: January 2012 to January 2014

Study Population:

\section{Inclusion Criteria}

All the specimens of modified radical mastectomy received in the Department of Pathology, Government Medical College, Thiruvananthapuram from $1^{\text {st }}$ January 2012 to $1^{\text {st }}$ January 2014.

\section{Exclusion Criteria}

- Histopathological diagnosis other than invasive ductal carcinoma

- carcinoma breast in males

\section{Methodology}

- Evaluation of clinical features

- Evaluation of Morphological Factors

In hematoxylin and eosin stained sections, various parameters namely tumour grade, histological type, mitosis, peritumoral tissue, venous invasion, host response and the number of lymph nodes involved by the tumour were studied.

Sections from tumor were also assessed for hormone receptor status namely estrogen and progesterone receptor status and graded using ALLRED scoring system.

Sections from peritumoral tissue were taken and stained with toluidene blue and giemsa for studying the distribution of mast cells.

Various prognostic factors analysed in the study may be defined as follows:

- Age, Tumour location,Tumour size

- Tumour grade: Tumour grading was done based on Modified Bloom Richardson scoring system:

- Histology: only tumors which had histology consistent with IDC-NOS was selected

- Vascular invasion: Vascular emboli were searched in the tumour as well as in adjacent tissues.

- Peritumoral tissue: The host immune response in peritumoral tissue was assessed as to whether there was 
lymphocytic infiltration or fibrosis or mast cells.

- Lymph nodes involved: ER ANDPR STATUS: asper ALLRED SCORING SYSTEM using adequate controls

\section{Patients were Stratified into 4 groups Based on Average Intensity Score of ER and PR Status}

Mast Cells: Sections from peritumoral areas are stained using toluidene blue and giemsa and mast cells are counted per high power field.

A case was taken as mast cell positive only if one or more mast cells were present in stromal areas of specimens in 10 high power fields in both giemsa and toluidene blue. ${ }^{i}$

Finally cases were compared with presence of mast cells in each with respect to their ER and PR status.

\section{Analysis}

Statistical analysis in the present study was performed using SPSS software. Univariate analysis was done using chi square test to detect the significance of mast cell presence with receptor status in invasive ductal carcinoma breast.

\section{Observations and Results}

The present study was done on the mastectomy specimens done for carcinoma breast received in the department of pathology, Government Medical College, Thiruvananthapuram during a period of two years from January 2012 to January 2014. A total of 150 cases were studied.

\section{Age Distribution}

In this study all the cases were divided into 3 groups based on age as <40yrs, 40-60yrs and >60 yrs. Majority of the cases were between 40-60 yrs (68\%) followed by $23 \%$ cases above 60 yrs. The youngest patient was 30 yrs old and oldest was 78 yrs old. (Table 1,Figure 1)

Table 1- Age Distribution

\begin{tabular}{|l|c|c|}
\hline Age (in years) & Frequency & Percentage \\
\hline$<40$ & 13 & $8.7 \%$ \\
\hline $40-60$ & 102 & $68.0 \%$ \\
\hline$>60$ & 35 & $23.3 \%$ \\
\hline Total & 150 & $100.0 \%$ \\
\hline
\end{tabular}

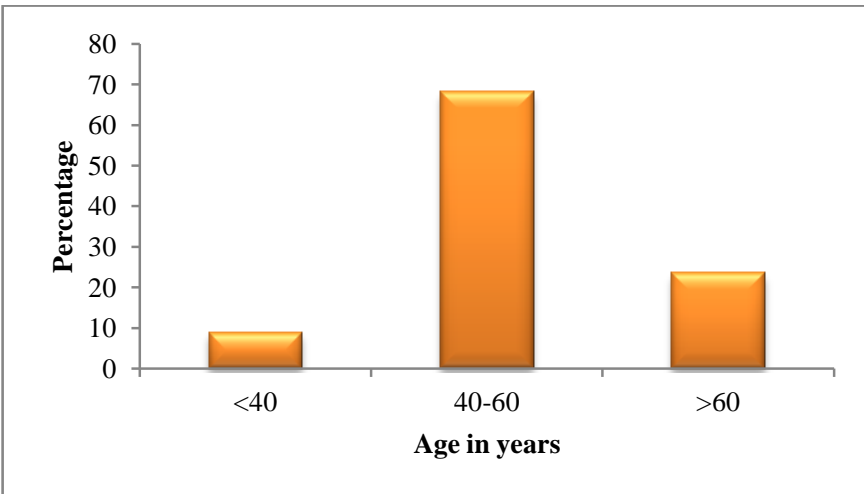

Figure 1 - Age Distribution

\section{Tumor Laterality}

Among 150 cases studied, most of the tumors $69(54 \%)$ were located on left side and 81 cases $(46 \%)$ were located on right side. Thus there was a slight predominance for left sided tumors. (Table 2,Figure 2)

Table 2- Tumor Laterality

\begin{tabular}{|l|c|c|}
\hline Tumor Laterality & Frequency & Percentage \\
\hline Right & 69 & $46.0 \%$ \\
\hline Left & 81 & $54.0 \%$ \\
\hline Total & 150 & $100.0 \%$ \\
\hline
\end{tabular}

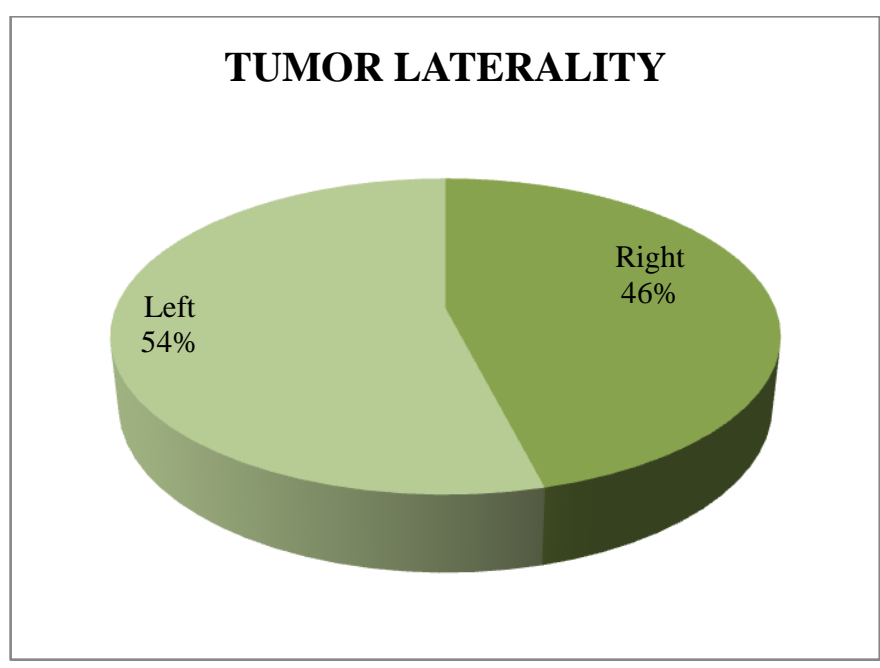

Figure 2-Tumor Laterality

\section{Tumor Size}

Tumor size was graded into 3 groups ie.a)Less than or equal to $2 \mathrm{~cm}$ size b)more than $2 \mathrm{~cm}$ to size less than or equal to $5 \mathrm{~cm}$ and c)more than $5 \mathrm{~cm}$ and majority of the cases ie 110 cases $(73.4 \%)$ had tumor size between 2 to $5 \mathrm{~cm}$. (Table 3,Figure 3) 
Table 3-Tumor Size

\begin{tabular}{|l|c|c|}
\hline Tumor Size $(\mathrm{Cm})$ & Frequency & Percentage \\
\hline$\leq 2$ & 14 & $9.3 \%$ \\
\hline$>2-\leq 5$ & 110 & $73.4 \%$ \\
\hline$>5$ & 26 & $17.3 \%$ \\
\hline Total & 150 & $100.0 \%$ \\
\hline
\end{tabular}

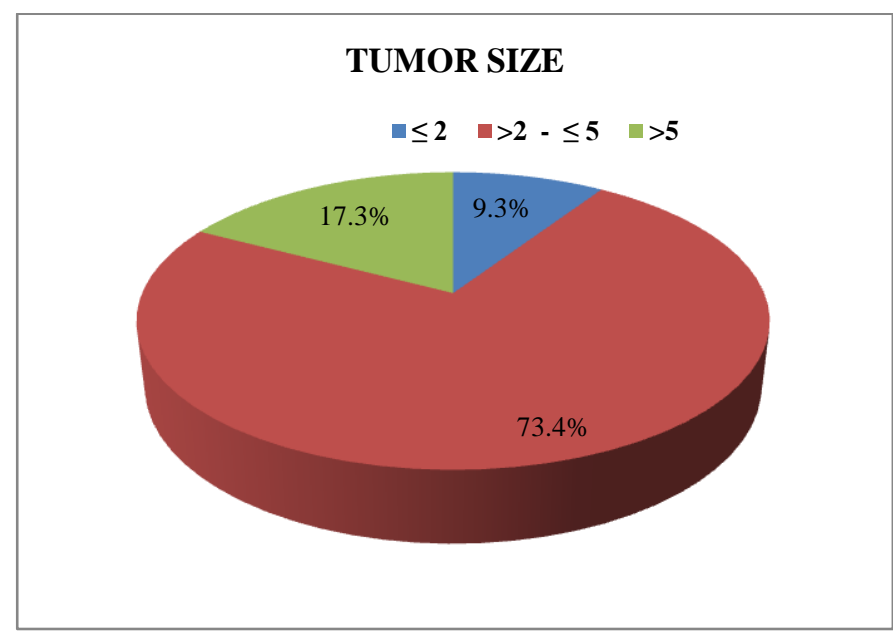

Figure 3- Tumor Size

\section{Histological Grade}

All the cases were graded using Modified Bloom Richardson grading (MBR) system. Out of the 150 cases studied 123 cases (82\%) belonged to grade 2 closely followed by $25(16.7 \%)$ cases in grade 3 and 2 cases (1.3\%) in grade 1.(Table 4,Figure 4)

Table 4-Histological Grade

\begin{tabular}{|l|c|c|}
\hline $\begin{array}{l}\text { HISTOLOGICAL } \\
\text { GRADE (MBR) }\end{array}$ & FREQUENCY & PERCENTAGE \\
\hline 1 & 2 & $1.3 \%$ \\
\hline 2 & 123 & $82.0 \%$ \\
\hline 3 & 25 & $16.7 \%$ \\
\hline Total & 150 & $100.0 \%$ \\
\hline
\end{tabular}

\section{HISTOLOGICAL GRADE (MBR)}

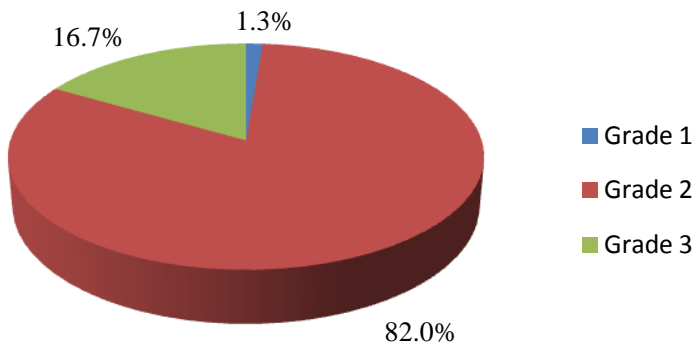

Number of Lymphnodes Involved by Metastasis

The patients were divided into 4 groups based on lymph node status. Majority of the cases had positive lymph nodes showing tumor(62.7\%) while 56 cases(37.3\%) had negative nodes.(table 5 ,figure 5)

Table 5-Lymphnode Involvement

\begin{tabular}{|l|c|c|}
\hline $\begin{array}{l}\text { Number Of Lymphnodes } \\
\text { Involved By Metastasis }\end{array}$ & Frequency & Percentage \\
\hline Nil & 56 & $37.3 \%$ \\
\hline $1-3$ & 42 & $28.0 \%$ \\
\hline $4-9$ & 39 & $26.0 \%$ \\
\hline$>10$ & 13 & $8.7 \%$ \\
\hline Total & 150 & $100.0 \%$ \\
\hline
\end{tabular}

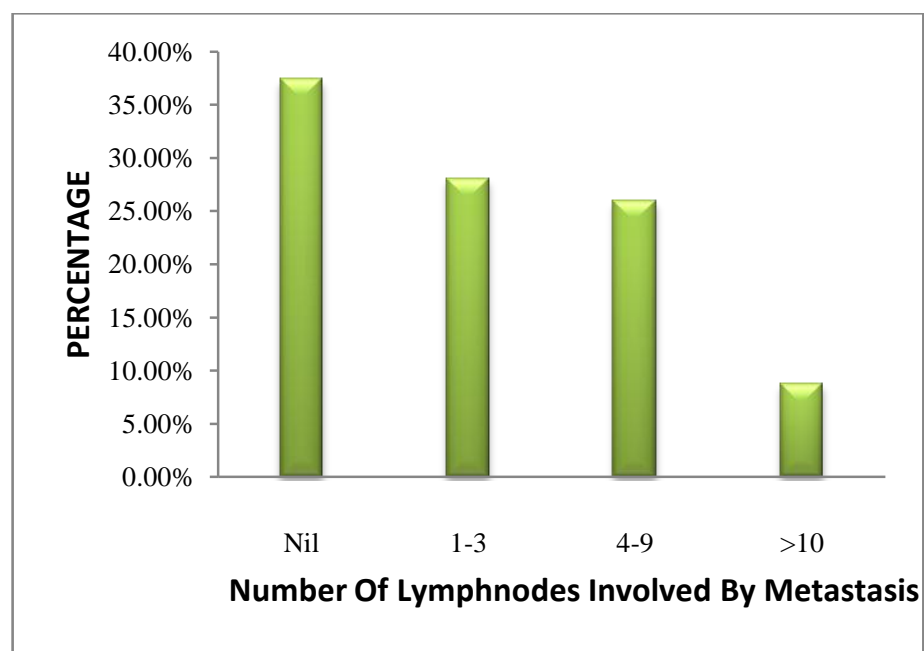

Figure 5- Lymphnode involvement

\section{Lymphovascular Invasion}

Out of 150 cases evaluated only 11 cases (7.3\%) showed features suggestive of tumor invading lymphatics or vessels. (Table 6,Figure6).

Table 6-Lymphovascular Invasion

\begin{tabular}{|l|c|c|}
\hline Lymphovascular Invasion & Frequency & Percentage \\
\hline Present & 11 & $7.3 \%$ \\
\hline Absent & 139 & $92.7 \%$ \\
\hline Total & 150 & $100.0 \%$ \\
\hline
\end{tabular}

Figure 4 -Histological grade 


\section{JMSCR Vol||05||Issue||10||Page 29499-29507||October}

\section{LYMPHOVASCULAR INVASION}

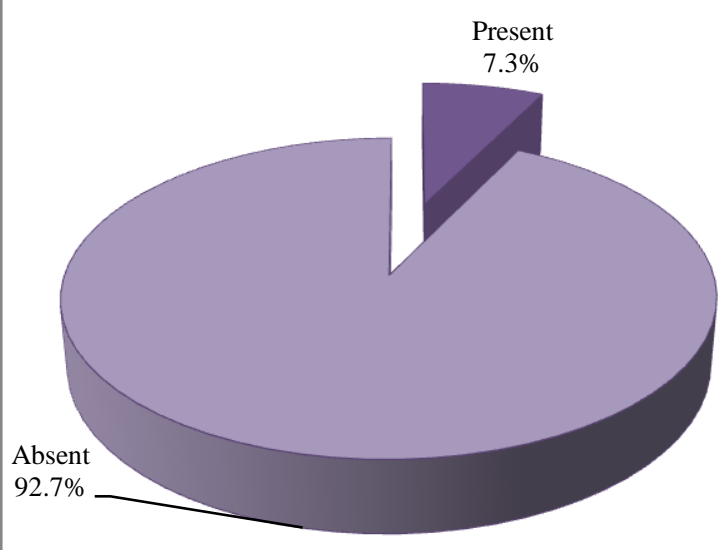

Figure 6-Lymphovascular Invasion

\section{Margin Involvement}

Margin involvement was found in only 26 cases (17.3\%) while 124 cases $(82.7 \%)$ showed no margin involvement by tumor cells. (Table 7 , Figure 7)

Table 7-Margin Involvement

\begin{tabular}{|l|c|c|}
\hline Involvement of Margins & Frequency & Percentage \\
\hline Present & 26 & $17.3 \%$ \\
\hline Absent & 124 & $82.7 \%$ \\
\hline Total & 150 & $100.0 \%$ \\
\hline
\end{tabular}

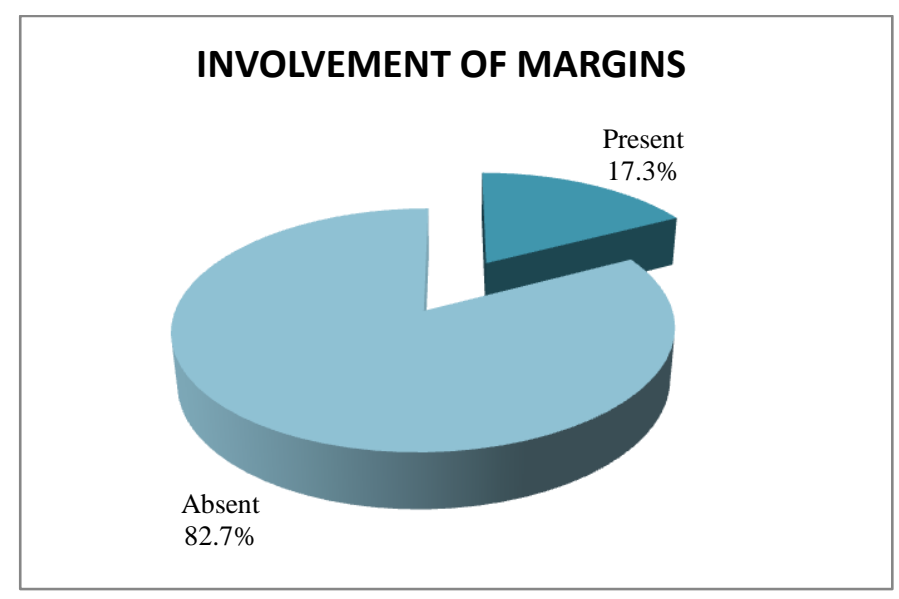

Figure 7- Involvement of Margins

\section{Estrogen Receptor Status}

Cases were analysed for Estrogen receptor status and graded using ALLRED scoring system and divided into 4 grades as strong positive, moderately positive, weak positive and negative. Majority of the cases ie.87 cases (58\%) showed positivity for Estrogen receptor. While 63 cases (42\%) showed Estrogen negativity. (Table 8,Figure 8)

Table 8- Estrogen Receptor Status

\begin{tabular}{|l|c|c|}
\hline Estrogen Receptor & Frequency & Percentage \\
\hline Absent & 63 & $42.0 \%$ \\
\hline Weak & 47 & $31.3 \%$ \\
\hline Moderate & 32 & $21.3 \%$ \\
\hline Strong & 8 & $5.3 \%$ \\
\hline Total & 150 & $100.0 \%$ \\
\hline
\end{tabular}

\section{Progesterone Receptor Status}

Progesterone receptor status assessed by ALLRED scoring system showed positivity in 74 cases $(49.3 \%)$ and $76(50.7 \%)$ cases showing progesterone negativity.(Table 9,Figure 8)

Table 9- Progesterone Receptor Status

\begin{tabular}{|l|c|c|}
\hline Progesterone Receptor & Frequency & Percentage \\
\hline Absent & 76 & $50.7 \%$ \\
\hline Weak & 40 & $26.7 \%$ \\
\hline Moderate & 24 & $16.0 \%$ \\
\hline Strong & 10 & $6.7 \%$ \\
\hline Total & 150 & $100.0 \%$ \\
\hline
\end{tabular}

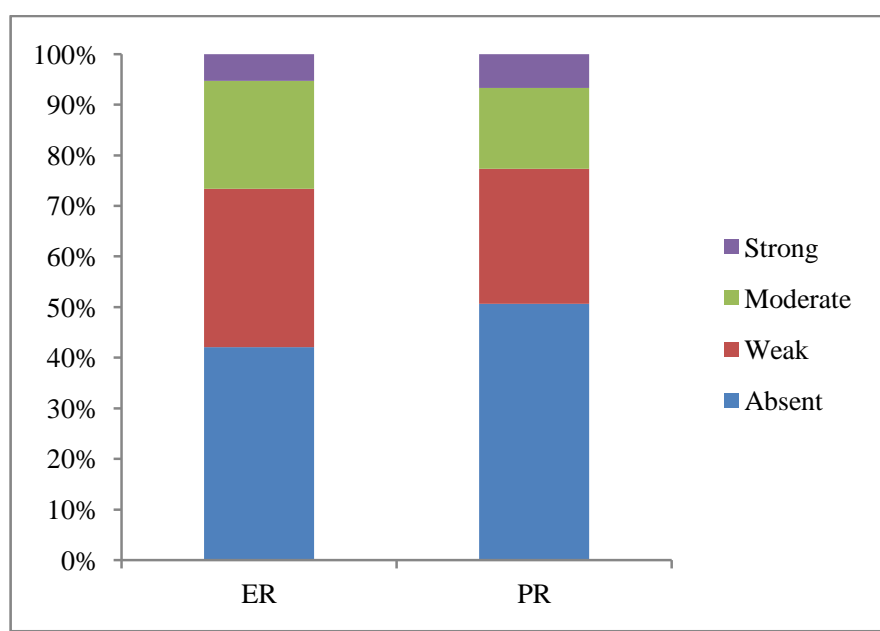

Figure 8-Estrogen and Progesterone Receptor Status

\section{Presence of Mast Cells}

Presence of mast cells in peritumoral tissue was assessed using special stains. The mast cells were present in 56 cases (37.3\%) and were absent in 94 cases $(62.7 \%)$. (Table 10, Figure 9) 
Table 10- Presence of Mast Cells

\begin{tabular}{|l|c|c|}
\hline Mast Cells & Frequency & Percentage \\
\hline Present & 56 & $37.3 \%$ \\
\hline Absent & 94 & $62.7 \%$ \\
\hline Total & 150 & $100.0 \%$ \\
\hline
\end{tabular}

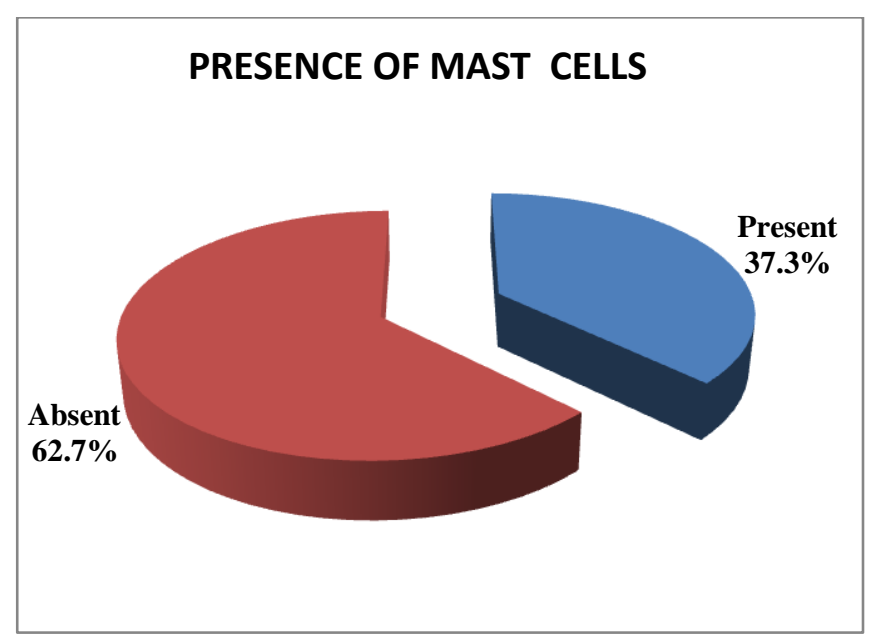

Figure 9-Presence of Mast Cells

\section{Presence of Ductal Carcinoma in Situ}

Presence of ductal carcinoma insitu component in adjacent breast tissue was present in 35 cases (23.3\%) while rest 115 cases(76.7\%) showed features like fibrosis, adenosis, inflammatory cell infiltrate etc. (Table 11, Figure 10)

Table 11-Presence of Ductal carcinoma In situ Component

\begin{tabular}{|l|c|c|}
\hline DCIS & FREQUENCY & PERCENTAGE \\
\hline Present & 35 & $23.3 \%$ \\
\hline Absent & 115 & $76.7 \%$ \\
\hline Total & 150 & $100.0 \%$ \\
\hline
\end{tabular}

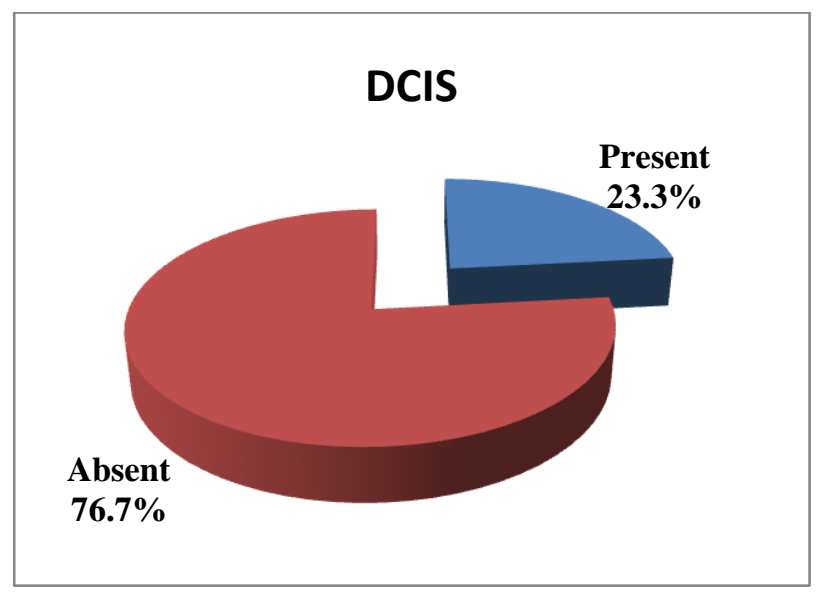

Figure 10 Presence of Ductal Carcinoma INSITU

\section{Mast cells and Hormonal Status}

The relationship between presence of mast cells and estrogen receptor positivity and progesterone receptor positivity was analysed separately using Chi-Square test. The result was found to be statistically insignificant as the p-value was more than 0.05. Thus there was no significant relationship between estrogen and progesterone receptor status with the presence of mast cells. (Table 12, Table 13)

Table 12-Mast Cells and Estrogen Receptor Status

\begin{tabular}{|l|c|c|c|c|c|c|}
\hline \multirow{3}{*}{ ER } & \multicolumn{4}{|c|}{ MAST cells } & \multirow{2}{*}{} \\
\cline { 2 - 6 } & \multicolumn{2}{|c|}{ Present } & \multicolumn{2}{|c|}{ Absent } & \multicolumn{2}{c|}{ Total } \\
\cline { 2 - 6 } & No: & $\%$ & No: & $\%$ & No: & $\%$ \\
\hline Absent & 18 & 32.1 & 45 & 47.9 & 63 & 42.0 \\
\hline Weak & 19 & 33.9 & 28 & 29.8 & 47 & 31.3 \\
\hline Moderate & 15 & 26.8 & 17 & 18.1 & 32 & 21.3 \\
\hline Strong & 4 & 7.1 & 4 & 4.3 & 8 & 5.3 \\
\hline Total & 56 & 100.0 & 94 & 100.0 & 150 & 100.0 \\
\hline
\end{tabular}

Table 13-Mast Cells and Progesterone Receptor Status

\begin{tabular}{|l|c|c|c|c|c|c|}
\hline \multirow{2}{*}{ PR } & \multicolumn{4}{|c|}{ MAST cells } & \multirow{2}{*}{} \\
\cline { 2 - 6 } & \multicolumn{2}{|c|}{ Present } & \multicolumn{2}{|c|}{ Absent } & \multicolumn{2}{c|}{ Total } \\
\cline { 2 - 6 } & No: & $\%$ & No: & $\%$ & No: & $\%$ \\
\hline Absent & 26 & 46.4 & 50 & 53.2 & 76 & 50.7 \\
\hline Weak & 16 & 28.6 & 24 & 25.5 & 40 & 26.7 \\
\hline Moderate & 11 & 19.6 & 13 & 13.8 & 24 & 16.0 \\
\hline Strong & 3 & 5.4 & 7 & 7.4 & 10 & 6.7 \\
\hline Total & 56 & 100.0 & 94 & 100.0 & 150 & 100.0 \\
\hline & \multicolumn{4}{|c|}{$p=0.703$} \\
$\chi^{2}=1.409 d f=3$ & $=3$ &
\end{tabular}

\section{Discussion}

As carcinoma breast is the most common cancer affecting women a clear knowledge regarding the different prognostic factors is very important. The detection of new factors helps us to implement newer treatment modalities which can be advocated as adjuvant treatment mainly to node negative patients. The detection of new factors like mast cells detected by simple techniques are seen to correlate with hormone status and so can be useful both as prognostic and treatment factor. The Present Study Included 150 Cases of Invasive Ductal Carcinoma Over A Period Of 2 Years 


\section{Age}

The mean age of patients was 54yrs which was similar to other studies. Comparing with other studies it was found to be comparable to findings by Baxter et al with mean age of 56.88 yrs. The majority of patients belonged to the age range of 40 to 60 yrs.

Table 14-Comparison of Age

\begin{tabular}{|l|c|}
\hline Study & Mean Age \\
\hline Dueck et al & 58.7 yrs \\
\hline Baxter et al $^{6}$ & $56.88 \mathrm{yrs}$ \\
\hline Chakraborthy et al $^{4}$ & $43.21 \mathrm{yrs}$ \\
\hline Present study & $54 \mathrm{yrs}$ \\
\hline
\end{tabular}

\section{Tumor Laterality}

Most common side affected by invasive ductal carcinoma breast was found to be leftside. Comparing with other studies it was similar to the findings by Stanec et $\mathrm{al}^{8}$ but dissimiliar to the observations made by Chakraborthyet $\mathrm{al}^{4}$ and Raychaudhari et $\mathrm{al}^{7}$ with most common side affected being right side.

Table 15- Comparison of Tumor Laterality

\begin{tabular}{|c|c|c|}
\hline Study & Right breast & Left breast \\
\hline Chakraborthy et al ${ }^{4}$ & $56.52 \%$ & $43.48 \%$ \\
\hline Raychaudhari et al $^{7}$ & $51.7 \%$ & $46.7 \%$ \\
\hline Stanec et al ${ }^{8}$ & $45.4 \%$ & $54.6 \%$ \\
\hline Present study & $46 \%$ & $54 \%$ \\
\hline
\end{tabular}

\section{Tumor Size}

In the present study it was seen that majority of the cases had tumorsize between $2 \mathrm{~cm}$ to $5 \mathrm{~cm}$ category which was comparable with the observations made by Rojananin et $\mathrm{al}^{11}$ and Tan $\mathrm{PH}$ et $\mathrm{al}^{12}$. However, Baxter et $\mathrm{al}^{6}$ found that predominant tumours size was less than $2 \mathrm{~cm}$. Rusby JE et al $^{13}$ categorisedtumour size into $\leq 2$ $\mathrm{cm}$ and $>2 \mathrm{~cm}$ and observed a higher proportion of tumours in $\leq 2 \mathrm{~cm}$ category (63\%).

Table 16 Comparison of Tumour Size

\begin{tabular}{|c|c|c|c|}
\hline Study & $\begin{array}{c}\text { Tumour } \\
\text { size } \leq 2 \mathrm{~cm}\end{array}$ & $\begin{array}{l}\text { Tumour size }>2 \\
\mathrm{~cm} \text { but } \leq 5 \mathrm{~cm}\end{array}$ & $\begin{array}{c}\text { Tumour size } \\
>5 \mathrm{~cm}\end{array}$ \\
\hline $\begin{array}{l}\text { Rojananin et } \\
\mathrm{al}^{11}\end{array}$ & $30.4 \%$ & $56.5 \%$ & $13.1 \%$ \\
\hline Tan PHet al $^{12}$ & $20 \%$ & $60 \%$ & $20 \%$ \\
\hline${\text { Baxter et } \mathrm{al}^{6}}^{6}$ & $60.1 \%$ & $27.8 \%$ & $12.1 \%$ \\
\hline Present study & $9.3 \%$ & $73.3 \%$ & $17.3 \%$ \\
\hline
\end{tabular}

\section{Histological Grade}

On grading invasive ductal carcinoma using Modified Bloom Richardson grading system in the present study, majority belonged to grade 2 . The results were in concordance with the published observations by Baxter et $\mathrm{al}^{6}$, Dueck et $\mathrm{al}^{5}$, Smith et $\mathrm{al}^{9}$ and Stanec et $\mathrm{al}^{8}$. The result was however in contrast with the observations made by De Rosa G et $\mathrm{al}^{10}$ who observed a predominance of grade 3 tumours. The difference may be due to interobserver variability in grading the tumours.

Table 17- Comparison of histological grade

\begin{tabular}{|c|c|c|c|}
\hline Study & Grade 1 & Grade 2 & Grade 3 \\
\hline${\text { Baxter et } \mathrm{al}^{6}}^{6}$ & $27.3 \%$ & $38.3 \%$ & $34.4 \%$ \\
\hline Dueck et al $^{5}$ & $18 \%$ & $42 \%$ & $40 \%$ \\
\hline Smith et $\mathrm{al}^{9}$ & $10 \%$ & $47 \%$ & $43 \%$ \\
\hline De Rosa $G$ et al ${ }^{10}$ & $9 \%$ & $33 \%$ & $58 \%$ \\
\hline stanec et $\mathrm{al}^{8}$ & $32.1 \%$ & $35.8 \%$ & $32.1 \%$ \\
\hline Present study & $1.3 \%$ & $82.0 \%$ & $16.7 \%$ \\
\hline
\end{tabular}

\section{Lymph Node Involvement}

In the present study metastasis from breast carcinoma to axillary lymph nodes was observed in $63.3 \%$ of cases. This was found to be similar to the result obtained by De Rosa $G$ et al $^{10}$ and Chattopadhyay BK et $\mathrm{al}^{7}$. However Baxter et $\mathrm{al}^{6}$, AC Dueck et $\mathrm{al}^{5}$ and Rusby JE et $\mathrm{al}^{13}$ noted less proportion of cases with lymph node involvement. In the present study, majority of the cases had between 1 to 3 lymph nodes being involved which was similar to the observations made by Rusby JE et al. ${ }^{13}$

Table 18- Comparison of Lymph node involvement

\begin{tabular}{|l|c|}
\hline Study & Lymph node involvement \\
\hline De Rosa G et al & $51 \%$ \\
\hline Chattopadhyay B K et al $^{7}$ & $57.5 \%$ \\
\hline Baxter et al $^{6}$ & $38.2 \%$ \\
\hline Dueck et al $^{5}$ & $36 \%$ \\
\hline Rusby JE et al & \\
\hline Present study & $44.1 \%$ \\
\hline
\end{tabular}

\section{Lympho-Vascular Invasion}

In the present study the cases showing positivity for lympho-vascular invasion formed a small proportion coming to $7.3 \%$. This was comparati- 
vely less than the observations made by Z.Stanecet $\mathrm{al}^{8}$, Duecket $\mathrm{al}^{5}$ and Rusby JE et al. ${ }^{13}$

Table 19-Comparison of Lympho-vascular Invasion

\begin{tabular}{|l|c|}
\hline Study & $\begin{array}{c}\text { Presence of lymphovascular } \\
\text { invasion }\end{array}$ \\
\hline Z.stanec et al & $23 \%$ \\
\hline Dueck et al $^{5}$ & $26 \%$ \\
\hline Rusby JE et al & 13 \\
\hline Present study & $41 \%$ \\
\hline
\end{tabular}

\section{Presence of Ductal Carcinoma in Situ Component}

In the present study Ductal carcinoma insitu component was observed in $35(23.3 \%$ ) cases which was slightly higher compared to the data published by Rojananin et $\mathrm{al}^{11}$. However, Rusby JE et $\mathrm{al}^{13}$ observed a much higher proportion of cases ie $41 \%$ with both invasive carcinoma and intraductal component.

Table 20-Comparison for the presence of DCIS component

\begin{tabular}{|l|c|}
\hline Study & $\begin{array}{c}\text { DCIS component + Invasive } \\
\text { Carcinoma }\end{array}$ \\
\hline Rojananin et al $^{11}$ & $15.6 \%$ \\
\hline Rusby JE et al & $54.7 \%$ \\
\hline Present study & $23.3 \%$ \\
\hline
\end{tabular}

\section{Oestrogen Receptor Status}

In the present study which was done with control, positivity for oestrogen receptor was observed in $58 \%$ of cases. This proportion is comparatively lesser than the observations noted in other studies.

Table 21- Comparison of Oestrogen Receptor Positivity

\begin{tabular}{|l|c|}
\hline Study & Oestrogen Receptor Positivity \\
\hline Baxter et al $^{6}$ & $74.4 \%$ \\
\hline Rusby JE et al $^{13}$ & $75 \%$ \\
\hline De Rosa G et al & \\
\hline Present study & $89.5 \%$ \\
\hline
\end{tabular}

\section{Progesterone Receptor Status}

In the present study which was done with control, positivity for progesterone receptor was observed in $49.3 \%$ of cases. This proportion is comparatively lesser than the observations noted in other studies.
Table 22-Comparison of Progesterone Receptor Positivity

\begin{tabular}{|l|c|}
\hline Study & Progesterone Receptor Positivity \\
\hline Baxter et al $^{6}$ & $65.7 \%$ \\
\hline De Rosa G et al & 10 \\
\hline Present study & $84.5 \%$ \\
\hline
\end{tabular}

\section{Presence of Mast Cells}

The presence of mast cells in tumor tissue was assessed using control and was found to be positive in $37.3 \%$ cases which was similar to study by M. Heidarpouretetal ${ }^{16}$ study by David Hunstman et $\mathrm{al}^{13}$ showed mast cell positivity in $26.7 \%$ cases. This variation might be due to the difference in techniques employed for the detection of mastcells.

Table 23- Comparison of Mast Cell Positivity

\begin{tabular}{|l|c|}
\hline Study & MAST CELL Positivity \\
\hline David Hunstman et al ${ }^{13}$ & $26.7 \%$ \\
\hline MitraHeidarpouret al $^{16}$ & $33.3 \%$ \\
\hline Present study & $37.3 \%$ \\
\hline
\end{tabular}

\section{Comparison of Hormonal Status and Presence of Mast Cell in Breast Carcinoma}

In the present study on analyzing the relationship between the presence of mast cells with the estrogen receptor status by chi square test it was found that there is no significant association between presence of mast cells in the peritumoral tissue and estrogen receptor status. This was similar to findings by ShahriarDabiri ${ }^{13}$ et al which showed that there was no significant relationship between estrogen receptor status and mast cells by conducting studies on 348 cases of invasive ductal carcinoma breast. It was dissimiliar to findings by Heidrapour ${ }^{16}$ et al which showed that stromal mast cells correlated to Estrogen receptor positivity and hence a good prognostic indicator.

The present study showed no relationship between progesterone receptor status with mast cells which was similar to the study findings by Mitra Heidrapour et al $^{16}$ and ShahriarDabri ${ }^{13}$ et al which also showed no correlation between the presence of stromal mast cells and PR positivity.

\section{Conclusion}

The present study showed that there is no significant relationship between presence of mast 
cells in peritumoral tissue and the hormonal status of the patient. So as per this study mast cell presence cannot be suggested as a definitive cheap easily assessable prognostic factor in carcinoma breast. Newer modalities for detection of new prognostic indicators can help in implementation of adjuvant therapies in a patient with ductal carcinoma breast.

\section{References}

1. Azizun-Nisa., Bhurgri, Y., Raza, F., Kayani, N. (2008). Comparison of ER, PR and HER-2/neu (C-erb B 2) reactivity pattern with histologic grade, tumor size and lymph node status in breast cancer..Asian Pacific Journal of Cancer Prevention :Apjcp, 9(4), 553-6.

2. Estrogen Receptor-Positive, Progesterone Receptor-Negative Breast Cancer: Association With Growth Factor Receptor Expression and Tamoxifen Resistance GraziaArpino, Heidi Weiss, Adrian V. Lee, Rachel Schiff, Sabino De Placido, C. Kent Osborneand Richard M. Elledge. JNCI J Natl Cancer Inst (7 September 2005) 97 (17): 1254-1261.

3. Khan K, Chakraborti S, Mondal S. Morphological predictors of nipple areola involvement in malignant breast tumours. Indian J Pathol Microbiol 2010;53(2):2327.

4. Billar JAY, Dueck AC, Gray RJ, Wasif N, Pockaj BA. Preoperative Predictors of Nipple-Areola Complex Involvement for Patients Undergoing Mastectomy for Breast Cancer. Ann SurgOncol 2011;18: 3123-28.

5. Wang J, Xiao X, Wang J, Iqbal N, Baxter L, Skinner KA, et al. Predictors of NippleAreolar Complex Involvement by Breast Carcinoma: Histopathologic Analysis of 787 Consecutive Therapeutic Mastectomy Specimens. Ann SurgOncol 2012;19: 1174-1180.
6. Saha K, Raychaudhuri G, Chattopadhyay BK. Clinico-pathological study of breast carcinoma: A prospective two-year study in a tertiary care hospital. Clin Cancer Investig J 2013;2(1):34-40.

7. Vlajcic Z, Zic R, Stanec S, Lambasa S, Petrovecki M, Stanec Z. Nipple-areola complex preservation: predictive factors of neoplastic nipple-areola complex invasion. Ann PlastSurg 2005;55(3): 240-4.

8. Brachtel EF, Rusby JE, Michaelson JS, Chen LL, Muzikansky A, Smith BL, et al. Occult nipple involvement in breast cancer: clinicopathologic findings in 316 consecutive mastectomy specimens. J ClinOncol 2009;27(30):4948-54.

9. D’Alonzo M, Martincich L, Biglia N, Pisacane A, Maggiorotto F, De Rosa G, et al. Clinical and radiological predictors of nipple-areola complex involvement in breast cancer patients. Eur J Cancer 2012.

10. Lohsiriwat V, Rojananin S, Bhothisuwan $\mathrm{K}$, Ratanawichitrasin A, O-charoenrat P, Jutaphisit S, et al.Prediction of Nipple Areolar Complex Involvement in Breast Cancer. Thai J Surg 2004;25(3):71- 78.

11. Fernandopulle SM, Cher-Siangang P, Tan PH. Breast carcinoma in women 35 years and younger: A pathological study. Pathology 2006;38:219-22.

12. Brachtel EF, Rusby JE, Michaelson JS, Chen LL, Muzikansky A, Smith BL, et al. Occult nipple involvement in breast cancer: clinicopathologic findings in 316 consecutive mastectomy specimens. J ClinOncol 2009;27(30):4948-54.

13. Dabiri S, Huntsman D, Makretsov N, Cheang M, Gilks B et al (2004) The presence of stromal mast cells identifies a subset of invasive breast cancers with a favorable prognosis. Mod Pathol 2004,17:690-95. 